\title{
Sensorial appraisal of sour cherries grown by environmental technology
}

\author{
Felföldi, J. ${ }^{1}$, Szabó, T. ${ }^{2}$, Nyéki, J, ${ }^{1} \&$ Szabó, Z. ${ }^{1}$ \\ ${ }^{1}$ University of Debrecen Centre for Agricultural and Applied Economic Sciences \\ H-4032 Debrecen, Böszörményi út 138., Hungary \\ ${ }^{2}$ Research and Extension Centre for Fruit Growing, H-4244 Újfehértó, Vadastag 2.
}

\begin{abstract}
Summary: Sour cherry samples have been tested by a panel of potential consumers, and the judgments expressed by points given for each attribute. The correlation of individual traits with "general impression" has been explored. Primary raising of data was aimed to evaluate the effect of environmental growing technology upon sensorial impression of fruits for fresh consumption. Organoleptic tests consist of tasting and filling out of forms with numerical data as ratings them regarding taste, flavour and flesh firmness. The values of coefficients of correlation showed that a couple of other attributes as appearance, juiciness and sugar/acids perceived were irrelevant from the point of view of acceptance, i. e. the general impression.
\end{abstract}

Key words: sour cherry, environmental growing technology, fresh consumption, fruit quality

\section{Introduction}

Consumer's attitudes in Hungary have been studied in relation to Hungarian fruits by Felföldi et al. (2008). Further information with apples is published by Vanczák et al. (2002) and Gonda et al. (2007), they dealt with an earlier period. The frequency of eating fruits is actually combined with the purchasing habits (TNS, 2009). The future of the whole fruit growing branch was the matter of a study of Apáti-Gonda (2010), with the outlooks of stone fruits see a paper of Szabó et al. (2010).

As a general purpose, we are concerned to stimulate fresh consumption of sour cherries, and we want to contribute with primary data to the topic with results and conclusions. The following program has been planned:

Sour cherry fruits grown by environmental technology were the object of a study, where six attributes were tested by sensorial methods: flesh firmness, juiciness, sugar/acid rate, flavour, taste and the appearance of the fruits. The next task was the study of interrelation of the attributes with the general impression (acceptance) of the samples, which is decisive from the point of view of purchasing. This study is a continuation of an earlier work, which is ready for publication.

\section{Materials and methods}

The sour cherry samples could be judged at the institute of Újfehértó, in 2010. Primary data were raised by judging organoleptically 15 sour cherry varieties grown by environmental technology. Participants of the panel filled after tasting a form with the listed attributes to be studied. The six attributes are: flesh firmness, juiciness, sugar/acid ratio, flavour, taste and the appearance of fruits. For the evaluation the results of 488 members judging the samples were used. Each attribute was rated on a scale of points between 0 and 9 . For characterising the varieties as general impression also on the same scale, 0-9, was done. The procedure of judging has been performed at three occasions, 2-3 hours each for 15 varieties.

The relations between individual attributes and the general impression are expressed by the coefficients of correlation. The coefficient chosen was Kendall' tau b. By the method of questioning, we may gain information, which cannot be obtained or only scarcely otherwise (Hoffmann et al., 2001). That is the way to achieve the comparability of the judgments.

\section{Results}

\section{The assortment studied in $\mathbf{2 0 1 0}$}

It was stated that the standard deviation was $4-9 \%$ of judgments made on the varieties: 'Érdi bőtermő', 'Favorit', 'Cigánymeggy', 'Érdi nagygyümölcsü' and 'Sipos-féle'. At the same time, the fruits of the rest of varieties, standard deviations were high, i.e. between $15-36 \%$. The flesh firmness of the most explored varieties was a matter of controversy, but also the sugar/acid ratio was judged very differently (Table 1).

Behind the values of deviations, the following mean values are found. In flesh firmness 'Érdi bőtermő', 
Table 1. The relative deviations from the mean values of the assortment of sour cherry varieties tested by sensorial method in $2010(\%)$

\begin{tabular}{|c|c|c|c|c|c|c|c|}
\hline Variety & 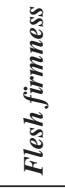 & 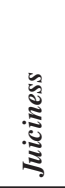 & 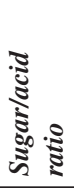 & 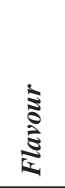 & 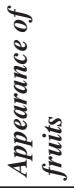 & 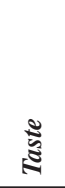 & 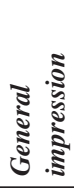 \\
\hline Érdi bőtermő & 6.9 & 7.9 & 6.7 & 7.6 & 8.7 & 7.9 & 8.2 \\
\hline Favorit & 4.5 & 7.1 & 5.8 & 6.6 & 6.9 & 6.6 & 6.6 \\
\hline Cigánymeggy 59 & 5.4 & 6.0 & 3.9 & 3.9 & 4.4 & 3.8 & 4.4 \\
\hline Érdi nagygyümölcsü & 6.4 & 7.1 & 6.7 & 6.5 & 8.1 & 6.8 & 7.1 \\
\hline Sipos-féle & 5.4 & 6.4 & 5.9 & 6.1 & 5.1 & 5.8 & 5.8 \\
\hline VN-4 & 45.4 & 39.5 & 31.3 & 26.2 & 17.5 & 24.7 & 21.5 \\
\hline VN-7 & 46.8 & 17.7 & 21.5 & 35.1 & 20.7 & 27.5 & 16.1 \\
\hline Csengődi & 38.7 & 19.1 & 35.3 & 28.5 & 23.6 & 21.9 & 20.0 \\
\hline Oblacsinszka & 39.3 & 20.6 & 14.3 & 30.5 & 28.7 & 41.3 & 34.1 \\
\hline VN-1 & 29.1 & 19.0 & 43.1 & 24.2 & 19.5 & 18.7 & 15.1 \\
\hline $\mathbf{A}$ & 29.7 & 24.8 & 16.9 & 27.9 & 24.8 & 24.2 & 24.0 \\
\hline $\mathbf{L}$ & 38.4 & 23.9 & 37.2 & 23.4 & 17.9 & 24.4 & 21.4 \\
\hline $\mathbf{E}$ & 30.1 & 28.0 & 19.9 & 26.8 & 26.1 & 22.8 & 23.4 \\
\hline N-2 & 57.2 & 35.8 & 44.7 & 46.8 & 32.7 & 40.7 & 36.5 \\
\hline Bosnyák & 26.6 & 21.5 & 26.2 & 25.1 & 17.7 & 26.5 & 24.2 \\
\hline
\end{tabular}

'Csengödi', 'VN-7' and 'Cigánymeggy' received values between 5.5 and 6.9. The highest value was 6.9 of 'Érdi bőtermö', but it happened that as low as 2.6 was proper for ' $\mathrm{N}-2$ '. The same variety was the less juicy with 4.5 as a mean, whereas the most juicy were 'VN-1' (7.14 as mean), 'Csengődi' (7.14), whereas 'Érdi bötermö' produced 7.86. The most appreciated sugar/acid ratio was found in 'A' and ' $E$ ' varieties with 7.2 and 8 points, but the lowest values in 'Érdi nagygyümölcsü' and 'N-2'. The best flavour appeared in 'Érdi bőtermö' and subsequently with less than one point the varieties 'VN-1', 'VN-7', 'Csengödi' and 'L'. Appearance of fruits received highest rating in 'Érdi bőtermő' and 'Csengődi', but also 'VN-4'. The best taste was found in 'Érdi bőtermö', 'VN-7', 'L', 'Csengődi' and 'Oblacsinszka'.

The rating of sour cherry varieties according to the general impression is shown in Figure 1.

More than 7 points have been given to 'Csengödi-0624' and 'VN-7', but outstanding was 8.21 of 'Érdi bőtermö', and less so with the lowest rate (4.07) the variety ' $\mathrm{N}-2$ '.

Table 2. Correlation between general impression and the single attributes with each other according to the sensorial tests of 2010

\begin{tabular}{|c|c|c|c|c|c|c|c|c|}
\hline & Kendall's tau_b & $\begin{array}{c}\text { flesh } \\
\text { firmness }\end{array}$ & juiciness & $\begin{array}{c}\text { sugar/ } \\
\text { acid ratio }\end{array}$ & flavour & appearance & taste & $\begin{array}{l}\text { general } \\
\text { impression }\end{array}$ \\
\hline \multirow{3}{*}{ flesh firmness } & coefficient of correlation & 1.00 & 0.10 & 0.12 & 0.19 & 0.23 & 0.20 & 0.33 \\
\hline & sign. (2-sided) & . & 0.01 & 0.00 & 0.00 & 0.00 & 0.00 & 0.00 \\
\hline & $\mathrm{N}$ & 489.00 & 488.00 & 488.00 & 488.00 & 488.00 & 488.0 & 488.00 \\
\hline \multirow{3}{*}{ juiciness } & coeffient of correlatiön & 0.10 & 1.00 & 0.13 & 0.33 & 0.34 & 0.34 & 0.41 \\
\hline & sign. (2-sided) & 0.01 & . & 0.00 & 0.00 & 0.00 & 0.00 & 0.00 \\
\hline & $\mathrm{N}$ & 488.00 & 488.00 & 488.00 & 488.00 & 488.00 & 488.00 & 488.00 \\
\hline \multirow{3}{*}{ sugar/acid ratio } & coefficient of correlation & 0.12 & 0.13 & 1.00 & 0.17 & 0.14 & 0.02 & 0.15 \\
\hline & sign. (2-sided) & 0.00 & 0.00 & . & 0.00 & 0.00 & 0.66 & 0.00 \\
\hline & $\mathrm{N}$ & 488.00 & 488.00 & 488.00 & 488.00 & 488.00 & 488.00 & 488.00 \\
\hline \multirow{3}{*}{ flavour } & coefficient of correlation & 0.19 & 0.33 & 0.17 & 1.00 & 0.32 & 0.55 & 0.55 \\
\hline & sign. (2-sided) & 0.00 & 0.00 & 0.00 & . & 0.00 & 0.00 & 0.00 \\
\hline & $\mathrm{N}$ & 488.00 & 488.00 & 488.00 & 488.00 & 488.00 & 488.00 & 488.00 \\
\hline \multirow{3}{*}{ appearance } & coefficient of correlation & 0.23 & 0.34 & 0.14 & 0.32 & 1.00 & 0.46 & 0.60 \\
\hline & sign. (2-sided) & 0.00 & 0.00 & 0.00 & 0.00 & . & 0.00 & 0.00 \\
\hline & $\mathrm{N}$ & 488.00 & 488.00 & 488.00 & 488.00 & 488.00 & 488.00 & 488.00 \\
\hline \multirow{3}{*}{ taste } & coefficient of correlation & 0.20 & 0.34 & 0.02 & 0.55 & 0.46 & 1.00 & 0.69 \\
\hline & sign. (2-sided) & 0.00 & 0.00 & 0.66 & 0.00 & 0.00 & . & 0.00 \\
\hline & $\mathrm{N}$ & 488.00 & 488.00 & 488.00 & 488.00 & 488.00 & 488.00 & 488.00 \\
\hline \multirow{3}{*}{ general impression } & coefficient of correlation & 0.33 & 0.41 & 0.15 & 0.55 & 0.60 & 0.69 & 1.00 \\
\hline & sign. (2-sided) & 0.00 & 0.00 & 0.00 & 0.00 & 0.00 & 0.00 & . \\
\hline & $\mathrm{N}$ & 488.00 & 488.00 & 488.00 & 488.00 & 488.00 & 488.00 & 488.00 \\
\hline
\end{tabular}




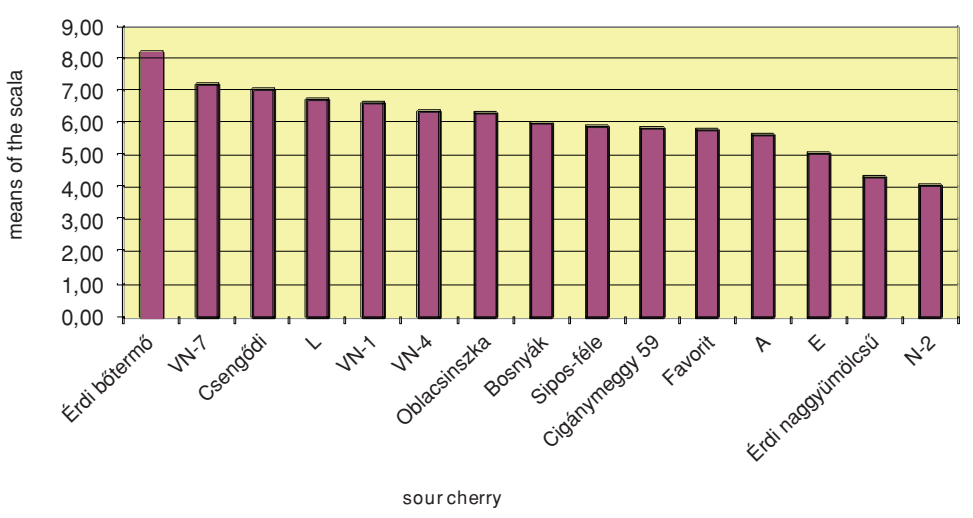

Figure 1. The rating of general impression given in 2010 to the sour cherry varieties

\section{Consequences}

Among the attributes of quality of fruit, the flesh firmness and juiciness proved to be active in determining the general impression. Calculated effects corroborated our expectation. The correlation of flesh firmness and juiciness means that if in a sample of high scores in flesh firmness lagged behind the other variety with high scores in juiciness. At the same time, no correlation between taste and sugar/acid ratio has been found. The three attributes: flesh firmness, juiciness and sugar/acid ratio, none of them was decisive alone regarding
The correlation between the attributes and general impression in sour cherries tested in 2010

Flesh firmness, juiciness, sugar/ acid ratio as the most important properties alone did not determine the general impression exerted on the members of the testing panel (Table 2).

Coefficients of correlation of attributes with the general impression are the following:

with flesh firmness 0.33 , with juiciness 0.41 , with sugar/acid ratio 0.15 . Those values are hardly decisive to prove the interdependence.

General impression and further three attributes show more correlation as flavour, appearance and taste. The values of the coefficients were 0.55 (flavour), 0.60 (outer appearance) and 0.69 (taste)

The linear equation of the regression with three main variable quantities:

$$
\hat{Y}=0.58+0.144 \mathrm{X}+0.289 \mathrm{X}_{2}+0.474 \mathrm{X}_{3} .
$$

The independent variables are the flesh firmness, outer appearance and taste. The multiple quotient of regression is $\mathrm{R}^{2}=0.748$, which means a tight correlation. According to the formula above, we computed the multiple regression quantities of general impression (Table 3).

According to the comparison of values measured with the calculated ones, the ranking order of the varieties tested in 2010 hardly changed (Table 4). The results corroborate our contention that by applying the equation of regression, we may find reliable solutions with a fewer number of attributes as indeüópendent variables of fruit quality to approach the dependent variable as general impression. This method seems to be suitable to be used for the organoleptic (sensorial) judgement of fruit quality as a sign of marketa bility.
Table 3. Values of general impression computed by linear regression (2010)

\begin{tabular}{|c|c|c|c|c|c|c|c|}
\hline $\begin{array}{c}\text { Computed } \\
\text { general } \\
\text { impression }\end{array}$ & constant & coefficient & $\begin{array}{c}\text { flesh } \\
\text { firmness }\end{array}$ & coefficient & appearance & coefficient & taste \\
\hline Ý & 0.58 & 0.144 & $\mathrm{X}$ & 0.289 & $\mathrm{X}_{2}$ & 0.474 & $\mathrm{X}_{3}$ \\
\hline 7.84 & 0.58 & 0.144 & 6.86 & 0.289 & 8.71 & 0.474 & 7.93 \\
\hline 6.67 & 0.58 & 0.144 & 5.48 & 0.289 & 6.52 & 0.474 & 7.21 \\
\hline 7.04 & 0.58 & 0.144 & 6.36 & 0.289 & 8.07 & 0.474 & 6.79 \\
\hline 6.30 & 0.58 & 0.144 & 4.72 & 0.289 & 6.00 & 0.474 & 6.97 \\
\hline 6.32 & 0.58 & 0.144 & 4.50 & 0.289 & 6.86 & 0.474 & 6.57 \\
\hline 6.35 & 0.58 & 0.144 & 4.93 & 0.289 & 7.27 & 0.474 & 6.23 \\
\hline 6.55 & 0.58 & 0.144 & 4.27 & 0.289 & 7.38 & 0.474 & 6.79 \\
\hline 5.82 & 0.58 & 0.144 & 4.23 & 0.289 & 5.92 & 0.474 & 6.15 \\
\hline 5.51 & 0.58 & 0.144 & 3.08 & 0.289 & 6.08 & 0.474 & 5.77 \\
\hline 6.07 & 0.58 & 0.144 & 5.52 & 0.289 & 6.34 & 0.474 & 6.03 \\
\hline 5.58 & 0.58 & 0.144 & 5.36 & 0.289 & 5.14 & 0.474 & 5.79 \\
\hline 5.54 & 0.58 & 0.144 & 5.00 & 0.289 & 5.87 & 0.474 & 5.37 \\
\hline 5.12 & 0.58 & 0.144 & 4.31 & 0.289 & 5.48 & 0.474 & 4.93 \\
\hline 4.42 & 0.58 & 0.144 & 5.43 & 0.289 & 4.36 & 0.474 & 3.79 \\
\hline 4.29 & 0.58 & 0.144 & 2.66 & 0.289 & 4.17 & 0.474 & 4.48 \\
\hline
\end{tabular}

Table 4. Differences between the measured (raised) and computed values of general impression in the case of the sour cherry varieties studied (2010)

\begin{tabular}{|c|c|c|c|}
\hline \multicolumn{2}{|c|}{ values of general impression } & \multicolumn{2}{|c|}{ differences } \\
\hline measured & computed (Ý) & $\begin{array}{c}\text { absolute } \\
\text { measured minus } \\
\text { computed) }\end{array}$ & $\begin{array}{c}\text { relative } \\
\text { difference/meas } \\
\text { ured) }\end{array}$ \\
\hline 8.21 & 7.84 & 0.37 & $5 \%$ \\
\hline 7.24 & 6.67 & 0.57 & $8 \%$ \\
\hline 7.07 & 7.04 & 0.03 & $0 \%$ \\
\hline 6.76 & 6.30 & 0.46 & $7 \%$ \\
\hline 6.64 & 6.32 & 0.32 & $5 \%$ \\
\hline 6.40 & 6.35 & 0.05 & $-4 \%$ \\
\hline 6.31 & 6.55 & -0.24 & $3 \%$ \\
\hline 6.00 & 5.82 & 0.18 & $7 \%$ \\
\hline 5.92 & 5.51 & 0.41 & $-4 \%$ \\
\hline 5.86 & 6.07 & -0.21 & $4 \%$ \\
\hline 5.79 & 5.58 & 0.21 & $2 \%$ \\
\hline 5.63 & 5.54 & 0.09 & $-1 \%$ \\
\hline 5.07 & 5.12 & -0.05 & $-1 \%$ \\
\hline 4.36 & 4.42 & -0.06 & -0.22 \\
\hline 4.07 & 4.29 & & \\
\hline
\end{tabular}


its effect on general impression. Three properties exerted mediocre or strong mediocre effects on general impression: they are taste, outer appearance and flavour. According to that, general impression is dependent first of all on those properties, which influence the rank of the sample.

By the use of the formula of regression, less attributes of quality are required to score the rank of samples judged by organoleptic methods without the danger of losing reliability. This new method is considered to be suitable to apply it in the rest of judging the quality of samples during the work planned for the period of the 2007-2010 years.

\section{Acknowledgement}

This paper was supported by the János Bolyai Research Scholarship of the Hungarian Academy of Sciences and NFÜ TECH $-08-\mathrm{A} 3 / 2-2008-0373$ grant.

\section{References}

Apáti, F. \& Gonda, I. (2010): The future of the Hungarian sour cherry growing branch. International Journal of Horticultural Science, 16, (1): 99-104.

Felföldi, J., Apáti, F., Szabó, V. \& Nábrádi, A. (2008): Fogyasztói attitüdök az almapiacon. Élelmiszer, Táplálkozás és Marketing The Hungarian Journal of Food, Nutrition and Marketing V.évf. 2008/23 sz. Kaposvári Egyetem, 87-92.

Gonda, I., Dremák, P., Vaszily, B. \& Rakonczás, N. (2007): Marketingprogram kidolgozása a hazai frissalma fogyasztás növelése érdekében, Kutatási jelentés

Hoffmann, M., Veres, Z. \& Kozák, Á. (2001): Piackutatás. Müszaki Kiadó, Budapest-

Szabó, Z., Soltész, M., Apáti, F. \& Nyéki, J. (2010): Conditions and outlooks of growing stone fruits. International Journal of Horticultural Science, 16, (1): 91-98.

TNS (2009): Vásárlói tudatosság. Progresszív Magazin. Crier Media Csoport. XVII. (4): 50p.

Vanczák, E., Takácsné György, K. \& Komáromi, N. (2002): A gyümölcs- és almafogyasztás helyzete, egy kérdőíves felmérés eredményei. Kertgazdaság. 34. (2): 55-60. 